Vol. 22 No. 1, 2021, 1-16

ISSN 1693-7619 | E-ISSN 2580-4170

Hompage: http://jurnal.umsu.ac.id/index.php/mbisnis

\title{
Peningkatan Kinerja Berbasis Manajemen Bakat, Servant Leadership Dan Komitmen Organisasi
}

\author{
Marno Nugroho ${ }^{1 *}$, Bagas Dewantoro Pamungkas Putro ${ }^{1}$ \\ Fakultas Ekonomi Universitas Islam Sultan Agung (UNISSULA) \\ Jl. Kaligawe Raya No.KM, RW.4, Terboyo Kulon, Kec. Genuk, \\ Kota Semarang, Jawa Tengah 50112, Indonesia \\ *Koresponden: marnonugroho@unissula.ac.id
}

\author{
Artikel Info \\ Received: \\ 31 Agustus 2020 \\ Revised: \\ 15 Januari 2021 \\ Accepted: \\ 14 April 2021
}

\begin{abstract}
ABSTRAK
Penelitian ini bertujuan untuk menganalisis pengaruh manajemen bakat dan servant leadership terhadap kinerja SDM melalui komitmen organisasi.Populasi dalam penelitian ini adalah seluruh karyawan PSDA-ESDM Semarang.Teknik pengambilan sampel dengan purposive random sampling yaitu teknik sampling yang menggunakan kriteria-kriteria atau pertimbanganpertimbangantertentu.Sampel yang diambil sebanyak 84 responden, dengan instrumen penelitian berupa kuesioner.Analisis data menggunakan regresi linier berganda.Hasil penelitian menunjukkan bahwa manajemen bakat berpengaruh positif dan signifikan terhadap komitmen organisasi, Servant leadership berpengaruh positif dan signifikan terhadap komitmen organisasi.Manajemen bakat berpengaruh positif dan signifikan terhadap kinerja SDM.Servant leadership berpengaruh positif dan signifikan terhadap kinerja SDM.Komitmen organisasi berpengaruh positif dan signifikan terhadap kinerja SDM.Komitmen organisasitidak mampu memediasi pengaruh manajemen bakat dan servant leadershipterhadap kinerja SDM.
\end{abstract}

Kata Kunci: Manajemen Bakat, Servant Leadership Komitmen Organisasi Dan Kinerja SDM

\section{Performance Improvement Based on Talent Management, Servant Leadership And Organizational Commitment}

\begin{abstract}
This study aims to analyze the effect of talent management and servant leadership on HR performance through organizational commitment. The population in this study were all employees of PSDA-ESDM Semarang. The sampling technique using purposive random sampling is a sampling technique that uses certain criteria or considerations. Samples taken were 84 respondents, with a research instrument in the form of a questionnaire. Data analysis uses multiple linear regression. The results showed that talent management had a positive and significant effect on organizational commitment, Servant leadership had a positive and significant effect on organizational commitment. Talent management has a positive and significant effect on $H R$ performance. Servant leadership has a positive and significant effect on HR performance. Organizational commitment has a positive and significant effect on $H R$ performance. Organizational commitment is not able to mediate the influence of talent management and servant leadership on HR performance.
\end{abstract}

Keywords: Talent Management, Servant Leadership Organizational Commitment and HR Performance

DOI: https://doi.org/10.30596/jimb.v22i1.5147

JEL CLASSIFICATION: O15, P17, J53

\section{Cara Sitasi :}

Nugroho, M., \& Putro, B. D. P. (2021). Peningkatan Kinerja Berbasis Manajemen Bakat, Servant Leadership Dan Komitmen Organisasi. Jurnal Ilmiah Manajemen dan Bisnis, 22(1), 1-16. https://doi.org/10.30596/jimb.v22i1.5147. 


\section{PENDAHULUAN}

Studi tentang Kinerja Sumber Daya Manusia sudah banyak dilakukan pada dasarnya kinerja dapat diuraikan tentang aspek aksi (behavioural) dan aspek outcome (Campbell,1990; Campbell, McCloy, Oppler, \& Sager, 1993; Kanfer, 1990; Roe, 1999). Performance is what the organization hires one to do, and do well" (Campbell et al., 1993, p. 40). Dalam hal ini kinerja individu akan diteliti aspek anteseden yang mempengaruhi.

Dalam prakteknya amat sulit memisahkan aspek aksi dan aspek outcome sehingga untuk menentukan kinerja haruslah disepakati ukuran maupun aspek yang dinilai. Kinerja adalah multi dimensional antara task performance dan contextual performance. Task Performance adalah unjuk kerja dari suatu pekerjaan sementara contextual performance berkaitan situasi baik lingkungan maupun personal yang dihadapi. Sehingga kinerja adalah konsep yang dinamis, bila yang berkaitan dengan kinerja individual.

Perubahan pengelolaan organisasi juga menyangkut perubahan pandangan tentang perilaku kepemimpinan. Mengingat arus tuntutan akan manajemen yang lebih etis, berpusat pada orang, kepemimpinan yang diilhami oleh ide-ide dari teori servant leadership menjadi relevan. Perhatian tentang semua pemangku kepentingan adalah kunci keuntungan jangka panjang bagi setiap organisasi. Kesehatan dan kesejahteraan karyawan diprioritaskan sehingga model/gaya kepemimpinan yang mengakar di dalamnya akan terkandung perilaku etis dan lebih peduli menyangkut hubungan pengikut-pemimpin. (Luthans, 2002; Macik-Frey, Quick, \& Cooper, 2009).

Penelitian Kusumowardani dan Suharnomo (2016) tentang komitmen organisasi adalah keadaan individu yang memihak organisasi serta tujuan-tujuan dan keinginannya untuk mempertahankan keanggotaannya dalam organisasi. Kuatnya komitmen dari karyawan pada perusahaan turut menjadi penentu bagaimana sifat dan tingkah laku karyawan tersebut selama berada dalam perusahaan. Komitmen organisasional mendorong karyawan untuk mempertahankan pekerjaannya dan menunjukkan hasil yang seharusnya. Karyawan yang memiliki komitmen yang tinggi terhadap perusahaan cenderung akan menunjukkan kualitas yang baik, lebih totalitas dalam bekerja. Hal tersebut dibuktikan dengan adanya temuan Sutrisno et al (2017), Pio et al (2015) dan Saryanto dan Amboningtyas (2016) yang menyatakan bahwa komitmen organisasi berpengaruh terhadap peningkatan kinerja karyawan.

Manajemen talenta merupakan pendekatan korporat yang terencana dan terstruktur untuk merekrut, mempertahankan dan mengembangkan orang-orang bertalenta dalam organisasi. Berdasarkan Gelens et al (2014) karyawan yang tidak memiliki bakat yang berharga dan unik akan sulit untuk memiliki komitmen terhadap organisasi. Sehingga semakin baik pengelolaan terhadap bakat (manajemen bakat) akan meningkatkan komitmen organisasi (Kontoghiorges, 2015).

Disisi lain, SDM yang berkualitas pun dapat menjadi pelengkap dari strategi fungsional lainnya, sehingga dapat membuat perusahaan jauh lebih percaya diri dalam menghadapi persaingan bisnis dan cenderung mendapatkan peningkatan keuntungan $20 \%$. Maka dari itu, tantangan perusahaan saat ini adalah untuk memenangkan perang talenta (talentwar), memenangkan perang talenta diharapkan akan berpengaruh kepada kemampuan memenangkan pasar (Octavia \& Susilo, 2018). Ini artinya, dengan adanya manajemen bakat apabila dikelola dengan tepat mampu memberikan keuntungan berupa adanya SDM yang handal dalam jumlah yang memadai untuk menepati posisi-posisi kunci perusahaan sehingga mampu menjamin keberlangsungan bisnis perusahaan (Kusumowardani \& Suharnomo, 2016). Selama beberapa tahun terakhir, studi kepemimpinan, mengarah kepada kepemimpinan transformasional menuju penekanan yang 
lebih kuat perspektif bersama, relasional, dan global di mana terutama interaksi antara pemimpin dan pengikut adalah elemen kunci (Avolio, Walumbwa, \& Weber, 2009). Sebelumnya berteori oleh Donaldson dan Davis (1991; Davis, Schoorman, \& Donaldson, 1997) menekankan pentingnya teori manajemen bergerak melampaui prinsipprinsip teori keagenan, asumsi homo economicus yang individualistis, oportunistik, dan mementingkan diri sendiri untuk tata kelola berdasarkan melihat individu sebagai proorganisasi, aktualisasi diri, danterpercaya.

Gaya kepemimpinan yang terbaru saat ini serta banyak diminati oleh para peneliti yaitu mengenai gaya kepemimpinan yang melayani (servant leadership) (Mira \& Margaretha, 2012). Servant Leadership hadir dengan membawa konsep yang cukup berbeda dengan konsep-konsep kepemimpinan sebelumnya. Karyawan yang seringkali dianggap sebagai bawahan justru dianggap sebagai prioritas utama dalam pemenuhan kebutuhan. Kondisi kenyamanan kerja dalam organisasi yang menjadi titik fokus perhatian para pemimpin dan membahas betapa pentingnya hubungan emosional antara pemimpin dengan karyawan dalam organisasi.

Pegawai dimotivasi oleh sesuatu yang lebih penting daripada kebutuhan akan kekuasaan, yaitu, kebutuhan untuk melayani (Luthans \& Avolio, 2003). Ini dapat dikaitkan dengan pekerjaan oleh McClelland dan Burnham (1976), yang sebelumnya menyatakan bahwa kebutuhan akan tenaga juga dapat digunakan untuk keuntungan cara yang efektif. Greenleaf melangkah lebih jauh dan menjadikan kebutuhan ini sebagai kunci menuju kebaikan kepemimpinan; itu mengarah pada komitmen terhadap pertumbuhan karyawan individu, kelangsungan hidup organisasi, dan tanggung jawab kepada komunitas (Reinke, 2004). Kekuasaan digunakan untuk melayani orang lain dan karena itu bahkan dapat dianggap sebagai prasyarat bagi pengikut-pemimpin; menjadi pemimpin berarti seseorang melayani.

Studi penelitian terdahulu terdapat perbedaan temuan mengenai pengaruh servant leadership terhadap kinerja karyawan, dimana pada temuan Paramita et al (2016), Apriliansyah (2018) dan Putri et al (2018) menyatakan bahwa servant leadership berpengaruh positif dan signifikan terhadap kinerja karyawan. Sedangkan temuan Kamanjaya etal (2017) menunjukkan bahwa servant leadership tidak berpengaruh terhadap kinerja karyawan.

Schuler (1992) menguraikan dalam mengelola SDM dikenal dengan prinsip 5P yaitu: Philosophy, Policies, Programs, Practices dan Processes bila prinsip tersebut selalu dikaitkan dengan tujuan organisasi maka pengelolaannya menjadi Manajemen SDM Strategik. Sementara Schuler and Jackson (2014) menguraikan efektifitas tentang apa yang dihadapi berikut praktek SDM yang berbeda antara kemarin dan sekarang.

Kinerja SDM adalah hasil kerja yang telah dicapai oleh karyawan yang berorientasi pada tujuan perusahaan. Setiap kinerja harus dinilai untuk mengetahui sejauh mana hasil kerja yang telah dicapai (Saryanto \& Amboningtyas, 2016). Sapitri (2016) menyatakan penilaian kinerja individu sangat bermanfaat bagi pertumbuhan perusahaan secara keselurahan. Penilaian Karywan tersebut akan dapat diketahui kondisi sebenarnya tentang bagaimana kinerja karyawan. Terdapat tujuh dimensi penilaian kinerja karyawan yang menjadi perhatian peneliti adalah kuantitas (Quantity of Work), kualitas (Quality of Work), pengetahuan kerja (Job knowledge), kerja sama (Cooperation), dapat diandalkan (Dependability), inisiatif (intiative), sikap (Personal qualities),

Kinerja SDM merupakan pencapaian yang dilakukan karyawan yang berorientasi pada tujuan perusahaan dan didorong dengan kemampuan alami yang dimiliki oleh SDM 
yang ada sehingga Kinerja SDM dapat diukur melalui beberapa indikator berikut adalah Kuantitas, Kualitas pekerjaan, Pengukuran ketepatan waktu

Manajemen Bakat adalah serangkaian inisiatif yang dilakukan perusahaan melalui proses mengidentifikasi, mengembangkan, dan mempertahankan karyawan yang bertalenta untuk menyelaraskan karyawan yang tepat dengan pekerjaan dan waktu yang tepat berdasarkan tujuan strategis perusahaan dan prioritas kegiatan perusahaan dengan mengoptimalkan kinerja karyawan bertalenta sehingga tercipta keunggulan bisnis dan tercapainya visi perusahaan (Kontoghiorges, 2015).

Talent management atau manajemen bakat adalah suatu proses manajemen SDM terkait tiga proses (Hermin Endratno, 2011). Pertama, mengembangkan dan memperkuat karyawan baru pada proses pertama kali masuk perusahaan (onboarding). Kedua, memelihara dan mengembangkan pegawai yang sudah ada di perusahaan. Ketiga, menarik sebanyak mungkn pegawai yang memiliki kompetensi, komitmen dan karakter bekerja pada perusahaan Simalango (2009)

Proses Manajemen Bakat biasanya dimulai dari proses rekrutmen, penempatan pegawai, penilaian kinerja, pelatihan danpengembangan karir hingga pegawai meninggalkan perusahaan. Gelen et al (2014) menyatakan bahwa Manajemen Bakat sangat bervariasi, sehingga pada praktiknya sangat berbeda ditiap perusahaan.

Berdasarkan uraian di atas, disimpulkan Manajemen Bakat merupakan pengelolaan karyawan sesuai dengan talenta atau bakat yang dimilikinya, dimana hal ini dimulai dari proses rekrutmen, penempatan pegawai, penilaian kinerja, pelatihan dan pengembangan karir hingga pegawai meninggalkan perusahaan yang diharapkan mampu meningkatkan keunggulan kompetitif perusahaan. Nugrahani dan Wulansari (2018) menyatakan beberapa indikator Manajemen Bakat, yakni pengalaman karier, potensi, inisiatif, kerjasama, tingkah laku, kualitas karakter, pribadi, jiwa pembelajar, servant leadership

Menurut Geenleaf dalam Putri et al (2018) menyatakan Servant Leadership adalah suatu kepemimpinan yang menggunakan perasaan tulus dari dalam hati untuk menjadi orang pertama yang melayani dan pilihan tersebut berasal dari dalam hatinya yang kemudian muncul keinginan untuk menjadi seorang pemimpin yang melayani.Servant Leadership (Kepemimpinan Pelayan) hadir dengan membawa konsep yang cukup berbeda dengan konsep-konsep kepemimpinan sebelumnya, yakni konsep yang lebih manusiawi dan lebih realistis untuk diaplikasikan dalam perkembangan organisasi di zaman sekarang.

Seger Handoyo (2010) meneliti beberapa dimensi dari servant leadeships antara lain: Wisdom, Organizational Stewardship service, humility, Emotional Healing. Sementara itu, indikator pengukuran servant leadership menurut Mira dan Meily (2012) yaitu terdiri dari kasih Sayang (Love), pemberdayaan (Empowerment), Visi (Vision), kerendahan hati (Humility), kepercayaan (Trust).

Komitmen organisasi merupakan sikap mengenai loyalitas pekerja terhadap organisasi dan merupakan proses yang berkelanjutan dari anggota organisasi untuk mengungkapkan perhatiannya pada organisasi dan hal tersebut berlanjut pada kesuksesan dan kesejahteraan (Saryanto \& Amboningtyas, 2016).

Studi Meyer (1999) membagi komitmen dalam 3 model Komitmen afektif, komitmen normative dan komitmen continuance. Setiap personel memiliki 3 aspek tersebut walaupun berbeda derajat kepentingannya. Peneliti lain mengembangkan bahwa dimensi continuance commitment terdiri dari dua faktor yang dapat dibedakan, satu merefleksikan "peran alternatif yang tersedia dalam keputusan untuk tetap pada pekerjaan seseorang" dan yang lain mengacu pada "pengorbanan pribadi yang akan dihasilkan dari meninggalkan organisasi" 
Timothy A. Jackson (2013) dalam studinya memaparkan tentang hubungan komitmen dengan kepemimpinan serta budaya. Studi menemukan bahwa terdapat hubungan antara berbagai tipe kepemimpinan (transformatif dan laissez faire) dengan berbagai macam komitmen dengan faktor budaya sebagai moderasi. Faktor budaya dengan skala Hofstede maupun Globe antara lain Individualism/kolektivism serta Power Distance.

Berdasarkan uraian di atas, dapat disimpulkan Komitmen Organisasi merupakan rasa loyalitas karyawan terhadap organisasi yang ditunjukkan dengan adanya sikap kedermawanan, kepercayaan dan penerimaan terhadap tujuan-tujuan dan nilai-nilai dari organisasi. Sartono et al (2018) menyatakan beberapa indikator komitmen organisasi adalah keinginan kuat sebagai anggota, keinginan berusaha keras dalam bekerja, penerimaan nilai organisasi, penerimaan tujuan organisasi.

\section{Pengembangan Hipotesis}

Nisa dan Astuti (2016) mengartikan manajemen bakat sebagai manajemen strategis untuk mengelola aliran bakat dalam suatu perusahaan yang bertujuan untuk memastikan tersedianya pasokan talent serta menyelaraskan pegawai yang tepat dengan pekerjaan dan waktu yang tepat berdasarkan tujuan strategis perusahaan serta prioritas kegiatan perusahaan atau bisnis perusahaan. Hasil yang bisa didapatkan perusahaan dengan menggunakan strategi manajemen talenta adalah mengisi posisi manajemen puncak dengan orangorang berkualitas, sehingga perusahaan tidak perlu meragukan kinerja karyawan yang akan diangkat menjadi bagian dari posisi puncak perusahaan. Hal tersebut berkaitan dengan teori bahwa investasi berupa manajemen bakat dapat menghasilkan pekerja yang berkualitas dan menghasilkan karya dengan kualitas kinerja yang tinggi, sehingga dapat diketahui bahwa adanya kaitan yang signifikan antara manajemen talenta dengan kinerja karyawan. (Octavia \& Susilo, 2018). Hal tersebut didukung dengan temuan Nisa dan Astuti (2016) dan Diniati et al (2018) yang menyatakan bahwa Manajemen Bakat berpengaruh positif dan signifikan terhadap Kinerja SDM. Berdasarkan uraian tersebut, maka hipotesis dalam penelitian ini adalah:

H1: Manajemen Bakat berpengaruh positif dan signifikan terhadap Kinerja SDM.

Servant Leadership adalah kepemimpinan yang mengedepankan pelayanan kepada pihak lain baik kepada karyawan yang timbul dari motivasi untuk membantu orang lain. Pelaksanaan Servant Leadership diketahui bentuk pelayanan yang dilakukan oleh pemimpin ditempatnya bekerja yang biasanya berupa mendengarkan pendapat dan memperhatikan aspirasi yang disampaikan oleh bawahan lalu melakukan peninjauan serta bersikap bijaksana dalam mengambil keputusan (Putri et al, 2018). Dengan kepemimpinan servant leadership yang melayani, mengayomi, memberi kasih sayang kepada bawahannya akan menumbuhkan produktivitas kerja yang tinggi untuk bawahan. Seorang bawahan akan lebih merasa dihargai dengan pimpinan yang rendah hati, tidak berlaku semena-mena sebagai seorang pemimpin. Perasaan tersebut akan menumbuhkan kesadaran tersendiri untuk bawahan agar dapat menjalankan apa yang diinginkan oleh pimpinannya tanpa harus diperintah secara langsung oleh pimpinan. Suasana tersebut akan menimbulkan kenyamanan dan kedamaian dalam organisasi yang berdampak positif terhadap kinerja SDM (Paramita et al, 2016). Pernyataan tersebut sejalan dengan temuan Putri et al (2018) dan Apriliansyah et al (2018) yang menyatakan Servant Leadership berpengaruh positif dan signifikan terhadap Kinerja SDM. Sedangkan Kamanjaya et al (2017) menyatakan bahwa Servant Leadership tidak berpengaruh terhadap Kinerja SDM. Berdasarkan uraian tersebut, maka hipotesis dalam penelitian ini adalah: 
H2 :Servant Leadership berpengaruh positif dan signifikan terhadap Kinerja SDM.

Organisasi dengan tujuan pertumbuhan di pasar global mulai menyadari bahwa prioritas harus didedikasikan untuk manusia.Dikatakan bahwa organisasi tidak berhasil dalam menemukan, melatih dan mempertahankan karyawan yang secara khusus dapat bekerja dalam budaya dan geografi yang berbeda.Perspektif bakat tidak terjadi pada fitur alami dari banyak organisasi.Namun, fakta ini mulai berubah saat ini, dan itu menjadi perpanjangan alami dari sumber daya manusia sambil menjadi lebih populer.Misi dan tanggung jawab organisasi dalam hal ini adalah untuk menarik bakat ke organisasi dan membuat strategi dan kebijakan untuk mengembangkan visi yang diperlukan untuk mempertahankan bakat.

Organisasi harus menentukan bakat dan potensi, merancang tahapan untuk memaksimalkan nilai yang dapat diberikan oleh karyawan yang mempunyai kemampuan khusus (bakat) dengan merencanakan pengembangan bakat dan membentuk pusat konsentrasi dala, rencana pengembangan ini.Manajemen bakat tidak hanya untuk memilih bakat yang tepat, tetapi untuk mengelola bakat yang ada secara efektif dan efisien.Seperti yang terlihat dalam penelitian di atas, komitmen karyawan dan implikasi manajemen bakat memiliki hubungan positif sedang di perusahaan-perusahaan ini (Vural et al, 2012).Pernyataan tersebut diperkuat dengan temuan yang dikemukakan oleh Kusumowardani dan Suharnomo (2016) dan Kontoghiorges (2015) yang menyatakan Manajemen Bakat berpengaruh positif terhadap Komitmen Organisasi. Berdasarkan uraian tersebut, maka hipotesis dalam penelitian ini adalah:

H3 :Manajemen Bakat berpengaruh positif dan signifikan terhadap Komitmen Organisasi.

Salah satu nilai utama servant leadership adalah kesetaraan dan keadilan yang mendorong serta mendukung perlakuan adil terhadap setiap orang, nilai tersebut bisa mempengaruhi persepsi bawahan untuk meningkatkan loyalitas dan komitmen organisasional mereka. Servant leadership memfokuskan agar pemimpin lebih peka dan perhatian terhadap masalah yang dimiliki oleh bawahan mereka, adanya rasa empati serta dapat mengembangkan mereka ke arah yang lebih baik (Kamanjaya et al, 2017). Tingkat servant leadership dapat dikembangkan dengan memberikan pemahaman yang mendalam mengenai melayani pihak lain dengan melakukan pendekatan secara menyeluruh pada pekerjaan, komunitas, serta proses pengambilan keputusan yang melibatkan semua pihak. Tindakan pemimpin yang secara terus-menerus mengembangkan karyawan (anggota organisasi) akan mengarahkan pada terciptanya kepuasan kerja dan meningkatnya komitmen karyawan terhadap perusahaan dan pekerjaannya secara signifikan (Akbar \& Mulyana, 2014). Hal ini sejalan dengan temuan Pio et al (2019) dan Kamanjaya et al (2017) yang menyatakan Servant Leadership berpengaruh positif dan signifikan terhadap Komitmen Organisasi. Berdasarkan uraian tersebut, maka hipotesis dalam penelitian ini adalah:

H4: Servant Leadership berpengaruh positif dan signifikan terhadap Komitmen Organisasi.

Komitmen organisasional merupakan suatu ikatan emosional antara karyawan dengan organisasi yang timbul karena adanya kepercayaan, kemauan untuk mencapai suatu tujuan serta keinginan untuk mempertahankan keanggotaan diri sebagai bagian dari organisasi dan hal tersebut yang menjadikan karyawan akan tetap bertahan dalam suatu organisasi baik dalam kondisi menyenangkan maupun tidak. Kuatnya komitmen dari karyawan pada perusahaan turut menjadi penentu bagaimana sifat dan tingkah laku 
karyawan tersebut selama berada dalam perusahaan. Komitmen organisasional mendorong karyawan untuk mempertahankan pekerjaannya dan menunjukkan hasil yang seharusnya. Karyawan yang memiliki komitmen yang tinggi terhadap perusahaan cenderung akan menunjukkan kualitas yang baik, lebih totalitas dalam bekerja (Sutrisno et al, 2017). Sehingga dapat disimpulkan bahwa Komitmen Organisasi berpengaruh positif dan signifikan terhadap Kinerja SDM, hasil tersebut sejalan dengan penelitian yang dilakukan oleh Pio et al (2015) dan Saryanto dan Amboningtyas (2016). Berdasarkan uraian tersebut, maka hipotesis dalam penelitian ini adalah:

H5 :Komitmen Organisasi berpengaruh positif dan signifikan terhadap Kinerja SDM.

Berdasarkan hipotesis di atas maka terbentuklah model empiris sebagai berikut:

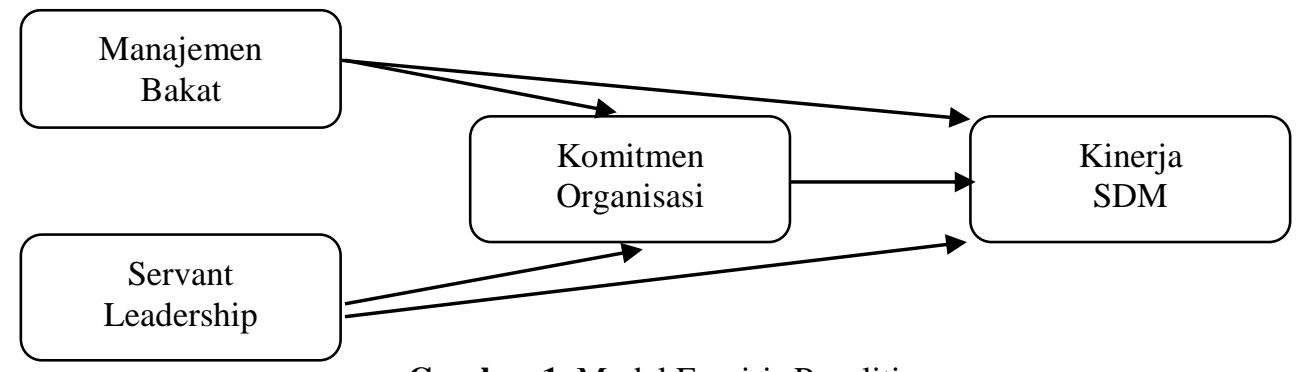

Gambar 1. Model Empiris Penelitian

\section{METODE}

Populasi pada penelitian ini adalah karyawan PSDA-ESDM Semarang yang berjumlah 515 dan dengan Teknik sampling didapatkan sampel sebanyak 84.Teknik penarikan sampling yang digunakan adalah purposive random sampling yaitu teknik sampling yang menggunakan kriteria-kriteria atau pertimbangan-pertimbangantertentu dalam menentukan sampel penelitian. Berikut merupakan kriteria dalam menentukan sampel tersebut: minimal sudah bekerja selama 3 tahun di PSDA-ESDM Semarang, berstatus sebagai PNS.

\section{HASIL DAN PEMBAHASAN}

Dengan alat bantu SPSS pengujian hipotesis model telah dilakukan dengan sebelumnya menguji kualitas data (validitas dan reabilitas) serta asumsi Klasik regresi. Selanjutnya dapat diketahui hasil regresi untuk menguji hipotesis penelitian.

Tabel 1. Hasil Uji Hipotesis

\begin{tabular}{lcccc}
\hline Pengaruh antar Variabel & $\begin{array}{c}\text { Beta } \\
\text { (koefisien) }\end{array}$ & t hitung & Sign. t & Keterangan \\
\hline $\begin{array}{l}\text { Manajemen Bakat } \rightarrow \text { Kinerja } \\
\text { SDM }\end{array}$ & 0.376 & 3.942 & 0.000 & H1 diterima \\
Servant Leadership $\rightarrow$ Kinerja & 0.332 & 3.483 & 0.001 & H2 diterima \\
SDM & 0.384 & 3.665 & 0.000 & H3 diterima \\
Manajemen Bakat $\rightarrow$ Komitmen & & &
\end{tabular}




\begin{tabular}{lllll}
$\begin{array}{l}\text { Organisasi } \\
\begin{array}{l}\text { Servant Leadership } \rightarrow \text { Komitmen } \\
\text { Organisasi }\end{array}\end{array}$ & 0.378 & 3.614 & 0.001 & H4 diterima \\
$\begin{array}{l}\text { Komitmen Organisasi } \rightarrow \text { Kinerja } \\
\text { SDM }\end{array}$ & 0.202 & 2.156 & 0.034 & H5 diterima \\
\hline
\end{tabular}

Berdasarkan pada Tabel 1 didapatkan persamaan regresi linier berganda sebagai berikut: Persamaan $1 \mathrm{KO}=0,384 \mathrm{MB}+0,378 \mathrm{SL}$; Persamaan $2 \mathrm{Y} 2=0,376 \mathrm{MB}+0,332$ $\mathrm{SL}+0,202 \mathrm{KO}$, dengan keterangan $\mathrm{MB}=$ Manajemen Bakat; $\mathrm{SL}=$ Servant Leadership; $\mathrm{KO}=$ Komitmen Organisasi; KSDM= Kinerja SDM.

\section{Pengujian Hipotesis}

Berdasarkan uji hipotesis didapatkan nilai $t$ hitung sebesar 3.942, dengan menggunakan level signifikan sebesar $5 \%$ diperoleh $\mathrm{t}$ tabel 1,990 yang berarti bahwa $\mathrm{t}$ hitung $3.942>\mathrm{t}$ tabel 1,990, dan nilai signifikan $0.000<0.05$ artinya hipotesis nol (H0) ditolak dan hipotesis alternatif (Ha) diterima. Hasil ini menunjukkan bahwa manajemen bakat berpengaruh positif terhadap kinerja SDM, artinya semakin baik manajemen bakat yang diterapkan dalam organisasi, maka akan meningkatkan kinerja para karyawan. Dengan demikian dapat disimpulkan bahwa hipotesis yang menyatakan manajemen bakat berpengaruh positif dan signifikan terhadap kinerja SDM diterima.

Berdasarkan uji hipotesis didapatkan nilai $\mathrm{t}$ hitung sebesar 3.483, dengan menggunakan level signifikan sebesar $5 \%$ diperoleh $\mathrm{t}$ tabel 1,990 yang berarti bahwa $\mathrm{t}$ hitung $3.483>\mathrm{t}$ tabel 1,990, dan nilai signifikan $0.001<0.05$ artinya hipotesis nol ( $\mathrm{H} 0)$ ditolak dan hipotesis alternatif (Ha) diterima. Hasil ini menunjukkan bahwa Servant Leadership berpengaruh positif terhadap kinerja SDM, artinya semakin baik Servant Leadership yang diterapkan dalam organisasi, maka akan meningkatkan kinerja para karyawan. Dengan demikian dapat disimpulkan bahwa hipotesis yang menyatakan Servant Leadership berpengaruh positif dan signifikan terhadap kinerja SDM diterima.

Berdasarkan uji hipotesis didapatkan nilai $\mathrm{t}$ hitung sebesar 3.665, dengan menggunakan level signifikan sebesar $5 \%$ diperoleh $t$ tabel 1,990 yang berarti bahwa $t$ hitung $3.665>\mathrm{t}$ tabel 1,990, dan nilai signifikan $0.000<0.05$ artinya hipotesis nol (H0) ditolak dan hipotesis alternatif (Ha) diterima. Hasil ini menunjukkan bahwa manajemen bakatberpengaruh positif terhadap komitmen organisasi, artinya semakin baik manajemen bakat yang diterapkan dalam organisasi, maka akan meningkatkan komitmen para karyawan. Dengan demikian dapat disimpulkan bahwa hipotesis yang menyatakan manajemen bakat berpengaruh positif dan signifikan terhadap komitmen organisasi diterima.

Berdasarkan uji hipotesis didapatkan nilai $\mathrm{t}$ hitung sebesar 3.614, dengan menggunakan level signifikan sebesar $5 \%$ diperoleh $\mathrm{t}$ tabel 1,990 yang berarti bahwa $\mathrm{t}$ hitung $3.614>\mathrm{t}$ tabel 1,990, dan nilai signifikan $0.001<0.05$ artinya hipotesis nol (H0) ditolak dan hipotesis alternatif (Ha) diterima. Hasil ini menunjukkan bahwa Servant Leadershipberpengaruh positif terhadap komitmen organisasi, artinya semakin baik Servant Leadershipyang diterapkan dalam organisasi, maka akan meningkatkan komitmen para karyawan. Dengan demikian dapat disimpulkan bahwa hipotesis yang menyatakan Servant Leadershipberpengaruh positif dan signifikan terhadap komitmen organisasi diterima.

Berdasarkan uji hipotesis didapatkan nilai $t$ hitung sebesar 2.156, dengan menggunakan level signifikan sebesar $5 \%$ diperoleh $\mathrm{t}$ tabel 1,990 yang berarti bahwa $\mathrm{t}$ hitung $2.156>\mathrm{t}$ tabel 1,990 , dan nilai signifikan $0.034<0.05$ artinya hipotesis nol $(\mathrm{H} 0)$ 
ditolak dan hipotesis alternatif (Ha) diterima. Hasil ini menunjukkan bahwa komitmen organisasiberpengaruh positif terhadap kinerja SDM, artinya semakin tinggi komitmen karyawan terhadap organisasi, maka akan meningkatkan kinerja para karyawan. Dengan demikian dapat disimpulkan bahwa hipotesis yang menyatakan komitmen organisasiberpengaruh positif dan signifikan terhadap kinerja SDM diterima.

Koefisien determinasi $\left(\mathrm{R}^{2}\right)$ digunakan untuk mengetahui seberapa besar pengaruh seluruh variabel independen terhadap dependen yang ada dan besarnya pengaruh variabel lain yang tidak dapat dijelaskan. Berikut hasil pengujian Koefisien Determinasi

Tabel 2. Uji Koefisien Derterminasi

\begin{tabular}{llcc}
\hline No & & R Square & Adjusted R Square \\
\hline 1 & Persamaan 1 & 0.476 & 0.463 \\
2 & Persamaan 2 & 0.631 & 0.617 \\
\hline
\end{tabular}

Berdasarkan Tabel 2 pada persamaan model 1 didapatkan Adjusted $R$ Square sebesar 0.463 , hal ini berarti variabel manajemen bakatdanservant leadership mampu menjelaskan variabel komitmen organisasi sebesar $46.3 \%$, sedangkan sisanya yaitu $53.7 \%$ dijelaskan oleh variabel lain yang tidak diteliti dalam penelitian ini.

Pada persamaan model 2 didapatkan didapatkan Adjusted $R$ Square sebesar 0.617, hal ini berarti variabel manajemen bakat, servant leadership dan komitmen organisasi mampu menjelaskan variasi kinerja SDMsebesar 61.7\%, sedangkan sisanya yaitu $38.3 \%$ dijelaskan oleh variabel lain yang tidak diteliti dalam penelitian ini.

\section{Uji Sobel}

Untuk membuktikan variabel komitmen organisasi apakah mampu menjadi variabel intervening antara pengaruh variabel manajemen bakat danservant leadership terhadap kinerja SDM, maka akan dilakukan uji sobel:

Pengaruh Manajemen Bakat Terhadap Kinerja SDM Melalui Komitmen Organisasi

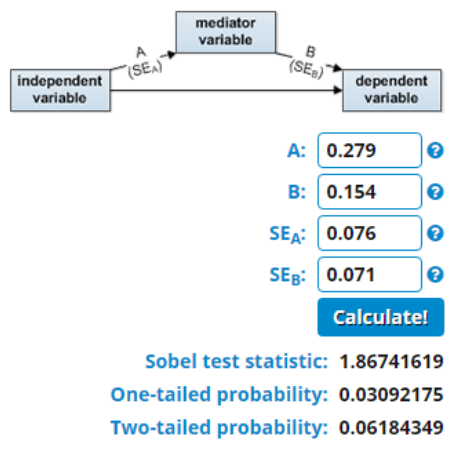

Gambar 2. Hasil Uji Sobel Test 1

Berdasarkan hasil pengujian dapat diketahui pengaruh tidak langsung langsung manajemen bakatterhadapkinerja SDM melalui komitmen organisasi yang diuji mengunakan uji sobel didapatkan nilai sobel statistik sebesar 1,867 dengan taraf signifikan 0,062 atau lebih besar dari 0,05. Dari hasil tersebut menunjukkan bahwa komitmen organisasitidak mampu memediasi pengaruh manajemen bakatterhadapkinerja SDM atau semakin baik organisasi dalam mengatur manajemen bakat karyawan maka akansecara langsung berdampak pada peningkatan kinerja SDM. 
Penjelasan tersebut berarti bila organisasi menempatkan karyawan sesuai dengan pengalaman karirnya demikian pula sesuai potensinya, juga sesuai kualitas karakternya serta ditempatkan diposisi yang dirasa ia mampu bekerjasama dengan karyawan lainnya maka akan berdampak pada peningkatan kinerja SDM baik dari kualitas, kuantitas maupun ketepatan waktunya.

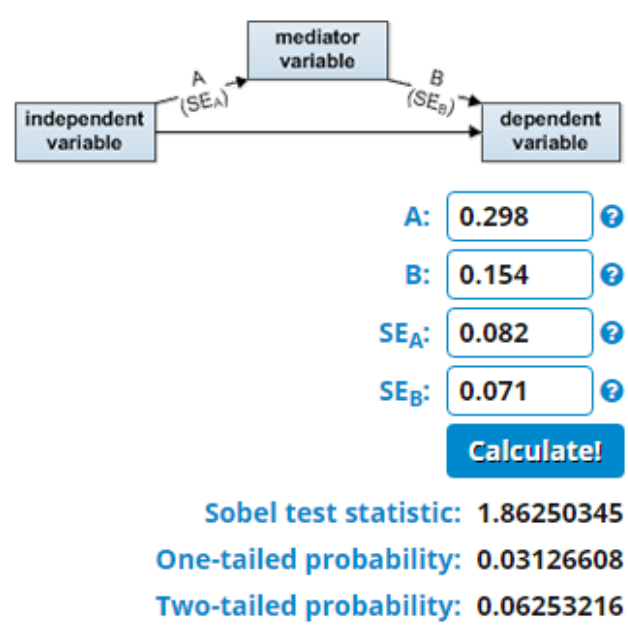

Gambar 3. Hasil Uji Sobel Test 2

Berdasarkan hasil pengujian dapat diketahui pengaruh tidak langsung Servant Leadershipterhadapkinerja SDM melalui komitmen organisasi yang diuji mengunakan uji sobel didapatkan nilai sobel statistik sebesar 1,862 dengan taraf signifikan 0,0625 atau lebih besar dari 0,05. Dari hasil tersebut menunjukkan bahwa komitmen organisasitidak mampu memediasi pengaruh Servant Leadershipterhadapkinerja SDM atau semakin baik Servant Leadershipyang ada didalam organisasimaka akan berdampak langsung pada peningkatan kinerja SDM.

Penjelasan tersebut berarti bila pemimpin menerapkan Servant Leadership dengan baik yaitu memimpin karyawannya dengan penuh kasih sayang serta selalu mendengarkan pendapat dari karyawannya dan mempunyai visi yang jelas untuk memajukan perusahaan serta memhormati konstribusi dari karyawan dan sudah dipercaya oleh karyawan maka akan berdampak langsung pada peningkatan kinerja SDM baik dari kualitas, kuantitas maupun ketepatan waktunya tanpa membentuk komitmen dari karyawan tersebut.

\section{Pembahasan}

\section{Pengaruh Manajemen Bakat TerhadapKinerja SDM}

Manajemen bakat terbukti mampu mendorong karyawan untuk menghasilkan kinerja yang optimal. Dengan adanya potensi yang dimiliki karyawan seperti mampu mengoperasikan komputer dengan baik, mampu melakukan negoisasi dengan baikmaka dengan mengelola bakat dan potensi mereka dengan baik maka akan meningkatkan kualitas kerja yang dihasilkan oleh para karyawan.

Manajemen bakat merupakan proses mengelola bakat karyawan yang bertujuan untuk memastikan tersedianya pasokan talent serta menyelaraskan kemampuan karyawan dengan posisi yang tepat, sesuai dengan potensi dan bakat sehingga dapat memaksimalkan kinerja yang dihasilkan karyawan. Hasil yang bisa didapatkan perusahaan dengan 
menggunakan strategi manajemen talenta adalah mengisi posisi manajemen puncak dengan orangorang berkualitas, sehingga perusahaan tidak perlu meragukan kinerja karyawan yang akan diangkat menjadi bagian dari posisi puncak perusahaan.

Manajemen bakat dapat menghasilkan pekerja yang berkualitas dan menghasilkan karya dengan kualitas kinerja yang tinggi, karena organisasi telah menempatkan karyawan sesuai dengan pengalaman karirnya, potensinya, kualitas karakternya serta ditempatkan diposisi yang dirasa ia mampu bekerjasama dengan karyawan lainnya. Jika karyawan ditempatkan sesuai dengan pengalaman karirnya makaia akan dapat bekerja dengan baik karena sudah terbiasa dan berpengalaman bekerja pada posisi tersebut, sehingga karyawan dapat menyelesaikan tugas dengan tepat waktu dan kualitas kerja yang baik. Selain itu jika karyawan ditempatkan sesuai dengan potensi yang dimilikinya maka karyawan tidak akan kesulitan dalam melaksanakan tugas yang diberikan sehingga kuantitas kerja yang dihasilkan, sesuai dengan target yang ditentukan. Jika karyawan ditempatkan pada posisi yang sesuai dengan karakternya maka karyawan akan lebih bersemangat untuk menunjukkan kemampuannya dan ia akan mampu bekerja sama dengan rekan kerja lainnya sehingga setiap tugas yang diberikan dapat seslesai dengan tepat waktu.

Hasil penelitian ini mendukung penelitian yang dilakukan oleh Nisa dan Astuti (2016) dan Diniati et al (2018) yang menyatakan bahwa Manajemen Bakat berpengaruh positif dan signifikan terhadap Kinerja SDM.

\section{Pengaruh Servant Leadership Terhadap Kinerja SDM}

Servant Leadership terbukti mampu mendorong karyawan untuk menghasilkan kinerja yang optimal. Semakin baik pemimpin memimpin dengan penuh kasih sayang maka akan membuat karyawan menjadi nyaman sehingga dapat mendorong karyawan untuk meningkatkan kualitas kerjanya. Servant Leadership adalah kepemimpinan yang mengedepankan pelayanan kepada karyawan dengan penuh kasih sayang dan ketulusan. Pelaksanaan Servant Leadership diketahui bentuk pelayanan yang dilakukan oleh pemimpin berupa mendengarkan pendapat dan memperhatikan aspirasi yang disampaikan oleh bawahan lalu melakukan peninjauan serta bersikap bijaksana dalam mengambil keputusan (Putri et al, 2018).

Dengan kepemimpinan servant leadership yang melayani, mengayomi, memberi kasih sayang kepada karyawan, mempercayai karyawanmaka akanmendorong karyawan menghasilkan kualitas dan kuantitas kerja yang baik. Seorang karyawanakan lebih merasa dihargai dengan pimpinan yang rendah hati, tidak berlaku semena-mena dan pemimpin yang mau mendengarkan pendapat karyawan. Jika pemimpin mau mendengarkan pendapat karyawan maka karyawan akan merasa dihargai sehingga karyawan lebih bersemangat dalam bekerja dan menghasilkan kuantitas kerja yang baik. Jika pimpinan mampu memberikan gambaran yang jelas mengenai masa depan perusahaan maka karyawan akan lebih termotivasi dalam bekerja karena merasa kesejahteraannya terjamin sehingga kualitas kerjanyapun meningkat. Selain itu jika pemimpin menghormati karyawan serta mengakui kontribusi karyawan terhadap organisasi maka akan menumbuhkan kepercayaan yang berdampak pada peningkatan kinerja para karyawan. Hasil penelitian ini mendukung penelitian yang dilakukan oleh Putri et al (2018) dan Apriliansyah et al (2018) yang menyatakan Servant Leadership berpengaruh positif dan signifikan terhadap Kinerja SDM.

\section{Pengaruh Manajemen Bakat Terhadap Komitmen Organisasi}

Manajemen bakat terbukti mampu mendorong karyawan untuk berkomitmen terhadap organisasi.Dengan adanya potensi yang dimiliki karyawan seperti mampu mengoperasikan komputer dengan baik, mampu melakukan negoisasi dengan baik maka 
dengan memanage bakat dan potensi mereka dengan tepat maka akan membuat karyawan menjadi betah bekerja diperusahaan karena perkerjaan yang dilakukannya sesuai dengan bakat dan potensi yang dimilikinya sehingga dapatmeningkatkan komitmen karyawan dan akan meningkatkan keinginan karyawan untuk tetap menjadi anggota organisasi.

Perusahaan harus menentukan bakat dan potensi, merancang tahapan untuk memaksimalkan nilai yang dapat diberikan oleh karyawan yang mempunyai kemampuan khusus (bakat) dengan merencanakan pengembangan bakat dan membentuk pusat konsentrasi yang sesuai dengan potensi karyawan sehingga dapat menimbulkan kenyamanan yang mendorong karyawan untuk berkomitmen terhadap organisasi.Manajemen bakat tidak hanya untuk memilih bakat yang tepat, tetapi untuk mengelola bakat yang ada secara efektif dan efisien sehingga membuat karyawan betah untuk tetap bekerja di perusahaan.Jika karyawan ditempatkan sesuai dengan pengalaman karirnya maka ia akan dapat bekerja dengan nyaman, sehingga karyawan memiliki keinginan kuat dalam bekerja dan berkonstribusi untuk organisasi. Selain itu jika karyawan ditempatkan sesuai dengan potensi yang dimilikinya maka karyawan akanmerasa bahwa pekerjaannya saat ini sudah cocok sehingga meningkatkan keingiingan karyawan untuk tetap menjadi anggota perusahaan. Jika karyawan ditempatkan pada posisi yang sesuai dengan karakternya maka karyawan akan lebih bersemangat untuk menunjukkan kemampuannya dan ia akan mampu menerima nilai-nilai yang ada dalam organisasi dan ikut dalam mewujudkan tujuan dari organisasi. Hasil penelitian ini mendukung penelitian yang dilakukan oleh Kusumowardani dan Suharnomo (2016) dan Kontoghiorges (2015) yang menyatakan Manajemen Bakat berpengaruh positif terhadap Komitmen Organisasi.

\section{Pengaruh Servant LeadershipTerhadap Komitmen Organisasi}

Servant Leadershipterbukti mampu mendorong karyawan untuk berkomitmen terhadap organisasi.Semakin baik pemimpin memimpin dengan penuh kasih sayang maka akan membuat karyawan menjadi nyaman sehingga dapat mendorong karyawan untuk berkomitmen menjadi anggota organisasi.Servant leadership memfokuskan agar pemimpin lebih peka dan perhatian terhadap masalah yang dimiliki oleh karyawan dan mengarahkannya kearah yang lebih baik.Hal tersebut dapat membuat karyawan nyaman berada dalam organisasi sehingga mereka lebih berkomitmen untuk ikut serta membantu organisasi untuk mencapai tujuannya.

Tingkat servant leadership dapat dikembangkan dengan memberikan perhatian kepada karyawan dan melayani karyawan dengan penuh kasih sayang, serta memberikan gambaran yang jelas mengenaivisi dari perusahaan dan juga melibatkan karyawan dengan mendengarkan pendapat yang diutarakan mereka sehingga dengan hal tersebut dapat membuat karyawan merasa dibutuhkan dan semakin berkomitmen untuk memajukan perusahaan. Jika pemimpin mau mendengarkan pendapat karyawan maka karyawan akan merasa dihargai sehingga karyawan lebih bersemangat untuk berkonstribusi bagi perusahaan. Jika pimpinan mampu memberikan gambaran yang jelas mengenai masa depan perusahaan maka karyawan akantermotivasi untuk tetap bertahan diperusahaan dan menjadi bagian dari perusahaan. Selain itu jika pemimpin menghormati karyawan serta mengakui kontribusi karyawan terhadap perusahaan maka karyawan akan lebih percaya terhadap perusahaan dan menerima nilai-nilai yang ada didalam perusahaan serta ingin membantu perusahaan dalam mencapai tujuan yang ditelah ditetapkan. Hasil penelitian ini sesuai dengan penelitian yang dilakukan oleh Pio et al (2019) dan Kamanjaya et al (2017) yang menyatakan Servant Leadership berpengaruh positif dan signifikan terhadap Komitmen Organisasi. 


\section{Pengaruh Komitmen OrganisasiTerhadap Kinerja SDM}

Komitmen Organisasiterbukti mampu mendorong karyawan untuk menghasilkan kinerja yang optimal. Semakin tinggi keinginan karyawan menjadi anggota organisasi maka akanmembuat karyawan memberikan kinerja yang maksimal guna mewujudkan tujuan dari organisasi. Semakin tinggi komitmen yang dimiliki karyawan, maka akan semakin meningkat kinerja karyawan dan akan meningkatkan kualitas keja karyawan .Komitmen organisasi adalah sesuatu yang membuat seseorang membulatkan hati, bertekad untuk berjerih payah, berkorban dan bertanggung jawab demi mencapai tujuan dirinya dan tujuan perusahaan yang telah disepakati atau ditentukan sebelumnya. Komitmen memiliki peranan penting terutama pada kinerja seseorang ketika bekerja, hal ini disebabkan oleh adanya komitmen yang menjadi acuan serta dorongan yang membuat mereka lebih bertanggung jawab terhadap kewajibannya.

Komitmen Organisasi timbul karena adanya ikatan emosional antara karyawan dengan organisasi yang timbul karena adanya keinginan yang keras dalam bekerja, kemauan untuk mencapai tujuan organisasi serta keinginan untuk mempertahankan keanggotaan diri sebagai bagian dari organisasi sehingga dapat mendorong karyawan untuk meningkatkan kinerjanya supaya dapat tetap berada diorganisasi. Aspek dalam komitmen organisasi seperti adanya keinginan untuk tetap berada diorganisasi dapat mendorong karyawan untuk tekun dalam bekerja dan juga berusaha untuk meningkatkan kualitas maupun kuantitas hasil kerja yang dihasilkan. Selain itu, komitmen organisasi akan mendorong karyawan untuk meningkatkan prestasi kerjanya sehingga dapat mendapatkan posisi kerja yang lebih baik. Dengan demikian dapat disimpulkan bahwa adanya kesadaran untuk berkomitmen terhadap organisasi akan membuat karyawan memiliki kinerja yang lebih baik. Hasil penelitian ini sesuai dengan penelitian yang dilakukan oleh Pio et al (2015) dan Saryanto dan Amboningtyas (2016) yang menyatakan komitmen organisasi berpengaruh positif dan signifikan terhadap Komitmen Organisasi.

\section{Pengaruh Tidak Langsung}

Hasil penelitian juga terbukti bahwa manajemen bakat akan lebih efektif dalam meningkatkan kinerja SDM dibandingkan melalui komitmen organisasi. Kekuatan manajemen untuk mengembangkan manajemen bakat yang baik, mampu mendorong karyawan memiliki mampu meningkatkan kualitas hasil kerja sehingga berdampak langsung pada kinerja SDM. Penjelasan tersebut berarti bila organisasi menempatkan karyawan sesuai dengan pengalaman karirnya, sesuai potensinya, sesuai kualitas karakternya serta ditempatkan diposisi yang dirasa ia mampu bekerjasama dengan karyawan lainnya maka karyawan akan dapat bekerja dengan baik dimana kualitas kerja yang dihasilkan akan semakin baik serta kuantitas kerjanya pun dapat optimal dan memiliki ketepatan waktu yang baik dalam menyelesaikan setiap tugas yang diberikan kepadanya.

Hasil penelitian juga terbukti bahwa Servant Leadership secara lebih efektif dapat meningkatkan kinerja SDM dibandingkan melalui komitmen organisasi. Adopsi Servant Leadership yang baik, mampu mendorong karyawan memiliki komitmen terhadap organisasi sehingga berdampak meningkatnya kinerja SDM. Penjelasan tersebut berarti bila pemimpin menerapkan Servant Leadership dengan baik yaitu memimpin karyawannya dengan penuh kasih sayang serta selalu mendengarkan pendapat dari karyawannya dan mempunyai visi yang jelas untuk memajukan perusahaan serta memhormati konstribusi 
dari karyawan dan sudah dipercaya oleh karyawan makakaryawan akan dapat bekerja dengan baik dimana kualitas kerja yang dihasilkan akan semakin baik serta kuantitas kerjanya pun dapat optimal dan memiliki ketepatan waktu yang baik dalam menyelesaikan setiap tugas yang diberikan kepadanya.

\section{SIMPULAN}

Manajemen bakat terbukti mampu mendorong karyawan untuk menghasilkan kinerja yang optimal. Hal ini berarti manajemen bakat yang baik dapat meningkatkan kinerja yang dihasilkan karyawan. Indikator manajemen bakat yaitu penenpatan sesuai pengalaman karir, sesuai potensi, mampu bekerjasama, sesuai kualitas karakter, berjiwa pembelajardapat meningkatkan kualitas dan kuantitas yang dihasilkan karyawan serta karyawan juga dapat menyelesaikan tugas dengan tepat waktu. Manajemen bakat yang baik dapat meningkatkan komitmen karyawan terhadap organisasi. Indikator manajemen bakat yaitu penenpatan sesuai pengalaman karir, sesuai potensi, mampu bekerja sama, sesuai kualitas karakter, berjiwa pembelajar dapat meningkatkan keinginan karyawan untuk tetap menjadi anggota organisasi, meningkatkan keinginan karyawanuntuk bekerja keras, mampu menerima nilai-nilai dalam organisasi serta mendorong karyawan untukikut serta mewujudkan tujuan dari organisasi. Servant Leadership terbukti mampu mendorong karyawan untuk menghasilkan kinerja yang optimal. Hal ini berarti Servant Leadershipyang baik dapat meningkatkan kinerja yang dihasilkan karyawan. Indikator Servant Leadership yaitu Love, Empowerment, Vision, Humility, Trust dapat meningkatkan kualitas dan kuantitas yang dihasilkan karyawan serta karyawan juga dapat menyelesaikan tugas dengan tepat waktu. Servant Leadership yang baik dapat meningkatkan komitmen karyawan terhadap organisasi. Indikator Servant Leadership yaitu Love, Empowerment, Vision, Humility, Trust dapat meningkatkan keinginan karyawan untuk tetap menjadi anggota organisasi, meningkatkan keinginan karyawan untuk bekerja keras, mampu menerima nilai-nilai dalam organisasi serta mendorong karyawan untuk ikut serta mewujudkan tujuan dari organisasi. Semakin tinggi komitmen organisasi maka akan meningkatkan kinerja yang dihasilkan karyawan. Indikator komitmen organisasiyaitu Keinginan kuat sebagai anggota, Keinginan keras dalam bekerja, Penerimaan nilai organisasi, Penerimaan tujuan organisasi dapat meningkatkan kualitas dan kuantitas yang dihasilkan karyawan serta karyawan juga dapat menyelesaikan tugas dengan tepat waktu.

Bagi penelitian yang akan datang disarankan untuk menggunakan teknik wawancara atau eksperimen secara langsung untuk menggali lebih lanjut mengenai manajemen bakat, servant leadership komitmen organisasi dan kinerja SDM sehingga akan didapatkan hasil yang lebih baik serta berguna untuk upaya meningkatkan kinerja para karyawan. Bagi penelitian berikutnya diharapkan menambah variabel bebas atau mengganti variabel yang sudah ada seperti organizational citizenship behavior (OCB), kepuasan kerja, budaya organisasi, lingkungan kerja dan lain-lain. 


\section{REFERENSI}

Akbar, F. A., \& Mulyana, O. P. (2014). Hubungan Antara Servant Leadership Dengan Komitmen Organisasi Pada Karyawan Rumah Sakit Delta Surya Sidoarjo. Jurnal Psikologi Teori \& Terapan, 140-151.

Apriliansyah, A., Astuti, E. S., \& Sulityo, M. C. (2018). Analisis Kompensasi dan Servant Leadership Pengaruhnya Terhadap Motivasi Kerja dan Kinerja Karyawan. Jurnal Administrasi Bisnis, 73-82.

Dirk van Dierendonck. (2011) Servant Leadership: A Review and Synthesis. Journal of Management,37,1228-1261

Diniati, I., Komariah, A., \& Kurniady, D. A. (2018). Implementasi Talent Manajemen dan Motivasi Kerja Implementasinya Pada Kinerja Pegawai Direktorat. Jurnal Administrasi Pendidikan, 294-306.

Gelens, J., Dries, N., Hofmans, J., \& Pepermans, R. (2014). Affective Commitment of Employees Designated as Talent : Signallling Perceived Organisational Support. European Journal International Management, 1-20.

Kamanjaya, I. G., Supartha, W. G., \& Manuati, D. I. (2017). Pengaruh Servant Leadership Terhadap Komitmen Organisasional dan Kinerja Pegawai. E-Jurnal Ekonomi dan Bisnis Uuniversitas Udayana, 2731-2760.

Kontoghiorges, C. (2015). Lingking High Performance Organizational Culture and Talent Management : Satisfaction/Motivation and Organizational Commitment as Mediators. The International Journal of Human Resource Mmanagement, 1-22.

Kusumowardani, A., \& Suharnomo. (2016). Analisis Pengaruh Manajemen Talenta dan Global Mindset Terhadap Kinerja Karyawan dan Turnover Intention Dengan Komitmen Organisasi Sebagai Variabel Intervening. Diponegoro Journal of Management, 1-15.

Mira, W. S., \& Margaretha, M. (2012). Pengaruh Servant Leadership Terhadap Komitmen Organisasi dan Organization Citizenship Behavior. Jurnal Manajemen, 189-206.

Nisa, R. C., \& Astuti, E. S. (2016). Pengaruh Manajemen Talenta dan Manajemen Pengetahuan Terhadap Kinerja Karyawan. Jurnal Administrasi Bisnis, 141-148.

Nugrahani, A., \& Wulansari, P. (2018). Pengaruh Penerapan Talent Management Terhadap Pengembangan Karier Pegawai Studi Kasus Pada Seluruh Pegawai Dibawah Anggota 1 Bidang Administrasi dan Umum Badan Pengusahaan Batam. e-Proceeding of Management, 354-359.

Octavia, H. V., \& Susilo, H. (2018). Pengaruh Manajemen Talenta Terhadap Kinerja Karyawan. Jurnal Administrasi Bisnis, 186-191.

Paramita, A. D., Suharnomo, \& Perdhana, M. S. (2016). Analisis Pengaruh Servant Leadership dan Budaya Organisasi Terhadap Kinerja Pegawai Dengan Kepuasan Kerja Sebagai Variabel Mediasi. Jurnal Bisnis dan Manajemen, 1-15.

Pio, R. J., Nimran, U., Alhabsji, T., \& Hamid, D. (2015). Pengaruh Kepemimpinan Spiritual Terhadap Perilaku Etis, Kualitas Kehidupan Kerja, Kepuasan Kerja, Komitmen Organisasional dan Kinerja Karyawan. DeReMa Jurnal Manajemen, 22-60.

Putri, D. P., Musadieq, M. A., \& Sulistyo, C. W. (2018). Pengaruh Servant Leadership dan Organizational Citizenship Behaviour Terhadap Kinerja Karyawan. Jurnal Administrasi Bisnis, 1-10.

Sanusi, A. (2011). Metode Penelitian Bisnis. Jakarta: Salemba Empat.

Sapitri, R. (2016). Pengaruh Komitmen Organisasi Terhadap Kinerja Karyawan Pperusahaan Listrik Negara Area Pekanbaru. JOM FISIP, 1-9. 
Sartono, M., Yulianue, \& Budi, L. (2018). Pengaruh Kompensasi, Motivasi Kerja dan Komitmen Organisasi Terhadap Turnover Intention. Journal of Management, 1-13.

Saryanto, \& Amboningtyas, D. (2016). Pengaruh Rotasi Kerja, Stres, Kepuasan Kerja dan Komitmen Organisasi Terhadap Kinerja Karyawan. Jurnal Bisnis dan Manajemen, 110.

Sutrisno, Haryono, A. T., \& Warso, M. M. (2017). Pengaruh Kepuasan Kerja dan Komitmen Organisasi Terhadap Kinerja Karyawan Melalui Organizational Citizenship Behavior Sebagai Variabel Intervening. Jurnal Bisnis dan Manajemen, 1-16.

Vural, Y., Vardarlier, P., \& Aykir, A. (2012). The Effects of Using Talent Management With Performance Evaluation System Over Employee Commitment. Procedia Social and Behavioral Sciences, 340-349. 